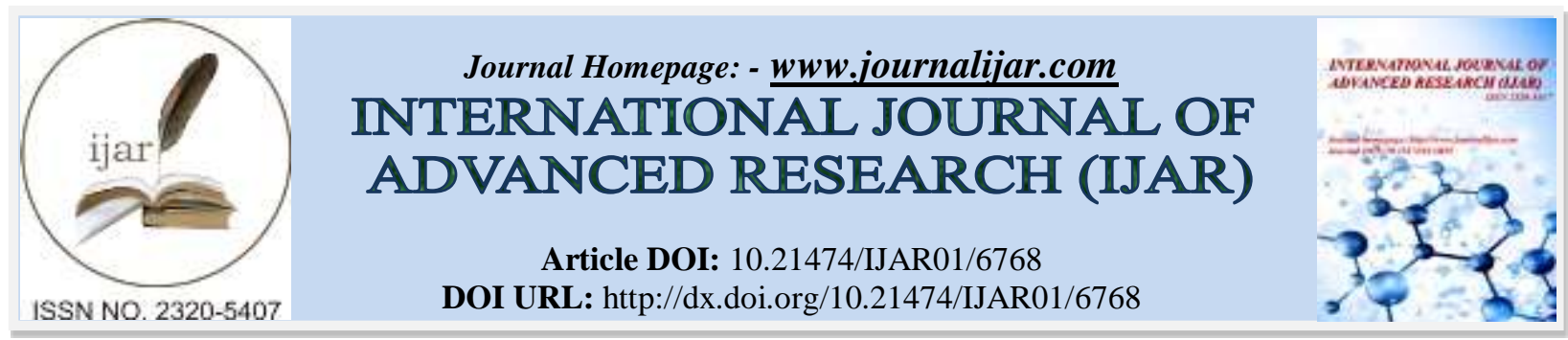

RESEARCH ARTICLE

\title{
PREVALENCE OF ASYMPTOMATIC HEPATITIS C VIRUS INFECTION IN EGYPTIAN CHILDREN PRESENTED WITH HEPATOMEGALY; SINGLE CENTRE STUDY.
}

M. S. Hemeda ${ }^{1}$, M. A. Gebreel. ${ }^{1}$, M.S. EL-Hakeem ${ }^{2}$, K. S. Hammad ${ }^{3}$ and A. S. Mansour ${ }^{1}$.

1. Department of Pediatrics, faculty of Medicine, Al Azhar University.

2. Department of Pathology, faculty of Medicine, Al Azhar University.

3. Department of Clinical Pathology, Faculty of Medicine, Al Azhar University.

\section{Manuscript Info}

\section{Manuscript History}

Received: 17 January 2018

Final Accepted: 19 February 2018

Published: March 2018

Keywords:-

Hepatitis C virus, Hepatomegaly,

Egyptian children.

\section{Abstract}

Objective: The aim of this study was to identify the prevalence of asymptomatic hepatitis $\mathrm{C}$ virus infection (HCV) in Egyptian children presented with hepatomegaly.

Methods: Prospective observational analytical single centre study for children with hepatomegaly selected from Paediatric outpatient Clinic and paediatric department at Sayed Galal Hospitals, AL-AzharUniversity, Cairo, Egypt.

Sixty child included in this work, there age ranged from 4 mo- 9 years and they were 42 male and 18 females, all children presented with hepatomegaly without any other hepatic manifestations, none of these children was diagnosed as having symptoms or signs of advanced liver disease upon clinical examination,

All children screened by ELISA for HCV and confirmed by HCV-RNA by RT-PCR.

Liver biopsy was done to HCV confirmed cases to confirm diagnosis and disease staging.

Results: Asymptomatic HCV infection was present in $6.7 \%$ in Egyptian children presented with hepatomegaly.

Conclusion: children with firm hepatomegaly must undergo screening for viral hepatitis even they are asymptomatic.

Copy Right, IJAR, 2018,. All rights reserved.

\section{Introduction:-}

Viral hepatitis is a public health problem affecting approximately 5 bilion people with death of about 1 milion each year (2.7\% of all deaths) from causes related to viral hepatitis, including liver cancer (1)It can be present with hepatomegaly in only $10 \%$ of cases.(2)In Egypt $4 \%$ of children with hepatitis have hepatomegaly without any hepatic manifestations, which discovered accidentally during routine examination.(3)

The problem of asymptomatic viral hepatitis has not been addressed in a serious way due to the silent or benign nature of the disease in its early stages, and the insidious course, as well as the long interval between infection and the expression of chronic liver disease or liver cancer.it is considered "the silent epidemic".(1)

4\% of Egyptian children with hepatitis infection have asymptomatic hepatomegaly discovered during routine examination(3).Senadhi recommended that HCV screening is warranted in all asymptomatic patients with mild 
transaminase elevations(7). Causes of viral hepatitis include hepatotropic viruses( HAV,HBV,HCV,HDV and HEV,In addition,Systemic infection that can affect the liver as Cytomegalovirus, Epstein-Barr virus, herpes etc (5) There are at least six HCV genotypes (1-6) and more than 50 subtypes. Genotype 1 is the most common and accounts for $75 \%$ of all HCV infections in the USA and Western Europe. (6)

Egypt has the highest prevalence of HCV in the world (13\%) (1).It accounts for $31 \%$ of acute viral hepatitis in Egyptwith 25-30\% of cases are symptomatic. (7) Symptoms typically develop 6-8 weeks after infection and last 312 weeks. Jaundice is observed in $25 \%$ of patients, while anorexia, abdominal pain, fatigue, nausea, vomiting, and fever are seen in 10-20\% of patients. Acute infection rarely progresses to fulminant hepatitis and acute liver failure)(8) Early in the course of infection, patients are seronegative for antibody to HCV (anti-HCV), but HCV RNA can be detected 1-2 weeks after exposure. The anti-HCV is detected 6-8 weeks after infection and usually persists for life. (9))Few studies have evaluated the epidemiology and risk factors of HCV infection in children in Egypt. Other studies showed the prevalence of HCV antibodies in Egyptian children was 3\% and 9\% in the Upper and Lower Egypt respectively.(10)Relatively few children with HCV undergo liver biopsy with only a few published series describing the histopathological findings in a significant number ofchildren (11)

Asymptomatic HCV infection is detectable in 2.02\% of Egyptian children, HCV infection is not always benign in the children as ALT levels are elevated in half of the subjects and histological abnormalities are detectable in three quarters of HCV-RNA positive cases, It is not clear whether identification of HCV early in childhood can alter the course of the disease due to the limitations of current antiviral therapies, Therefore long-term morbidity of the disease is a concern..(12)

\section{Patients and methods:- \\ Study design:}

This study is a prospective observational analytic single center study for children with asymptomatic hepatomegaly randomizly selected from Paediatric outpatient Clinic and paediatric department at Sayed Galal university Hospitals, AL-Azhar-University, Cairo, Egypt .Sixty children (42 male \& 18 female) their age ranged from (4months to9 years)were recruited in the study,in 2 years duration, presented by different complains accompanied by hepatomegaly without any hepatic manifestations. This study was approved by the Hospital Research Ethics Committee and has been performed in accordance with the ethical standards as in Declaration of Helsinki (1964)and its later amendments, and a written informed consent was obtained from parents for any procedures, investigations and publication of the results of this study in the medical literature.Normal liver size estimations are based on agerelated clinical indices, such as the degree of extension of the liver edge below the costal margin as well as the span of dullness to percussion. In children, the normal liver edge can be felt up to $2 \mathrm{~cm}$ below the right costal margin. Measurement of liver span is carried out by percussing the upper margin of dullness and by palpating the lower edge in the right midclavicular line. Reference values for hepatomegaly were based on the table of normal span of hepatomegaly according to the age by Bickly et al (13)

\section{Exclusion criteria: all babies with manifest liver disease or signs of liver dysfunction.}

All patients underwent the following:

Thorough history taking including personal, present, past, family,developmental,dietetic, vaccinationand social. Full general and hepatic examination were done.

They underwent laboratory investigations;Complete blood count (CBC),C-reactive protein (CRP) ,ESR, renal functions (Serum creatinine\& urea) liver functions: ALT\&AST ,Serum albumin, Serum total \& bilirubin , PT and lipid profile.

Detection of anti HCV antibodies by ELISA kits (REF 10521, VEDA.LAB, ALENCON CEDEXFRANCE)andTaqMan Realtime PCR in patient with positive ELIZA.

Each sample was labeled with patient's name and an identification number.

All cases underwent abdominopelvic ultrasonography using Siemens-Adara ultrasound machine -Japan.

Liver Biopsy done for each child with firm hepatomegaly and positive serological tests (4 cases). 
Before biopsy we investigated all cases for coagulation profile .Ultrasound guided percutaneous liver biopsy was done with Tru-Cut needle in the prone position with local anesthesia and sedation. A tissue specimen lodged in a niche in the obturator needle is excised by a second cylindrical needle sliding over it. To this end the needle is advanced into the liver and the sliding mechanism is triggered automatically ("biopsy gun"); the needle is then withdrawn from the liver.The specimen is recovered from the obturator needle and placed in two container one $10 \%$ formalin and the other normal saline $0.9 \%$ and sent for histopathological examination.

Our plan in this work was that all children with asymptomatic hepatomegaly will be investigated by ELISA and PCR for HCV Children and liver biopsy to confirm diagnosis and disease staging.

\section{Statistical analysis:}

Statistics were done by computer using SPSS version 20.

Statistics program .The tests used were : X mean, SD standard deviation : to measure the central tendency of data and the distribution of data around their mean.

Student's $\mathrm{t}$ test: for testing statistical significant difference between means of two samples. X2 test (Chi square test) to test statistical significant relation between different variable or grades (qualitative data) or percentages.

$\mathrm{Z}$ test to test statistical significant difference between two percentages.

-Significant result is considered if $\mathrm{p}<0.05$.

-Highly significant result is considered if $\mathrm{p}<0.01$

\section{Results:-}

The studied cases were subjected to analytical data recording .They were 42 males (70\%) and 18 females (30\%) .The mean age of cases was $26.75 \pm 21.45$ months.(table 1). As regard initial presentation of cases, chest problem(respiratory distress and cough )was the most common presenting complain (55\%), neurological symptoms (delayed development and convulsions ) in $23.3 \%$ then abdominal symptoms in $(15 \%)$ and others as fever arthralgia and short stature (6.7\%).(table2).Positive family history for consanguinity in $40 \%$ while that of hepatitis in $6.7 \%$ of cases .(table 3)

Table 1:- demograghic data of the studied cases

\begin{tabular}{|l|ll|}
\hline Variables & Number & $\mathbf{( \% )}$ \\
& $\mathbf{N = 6 0}$ & $\mathbf{1 0 0}$ \\
\hline Gender & & \\
Males & 42 & 70 \\
Females & 18 & 30 \\
\hline Age range (months) & Mean \pm SD \\
& $26.75 \pm 21.54$ months \\
\hline
\end{tabular}

Table 2:- Initial case presentation:

\begin{tabular}{|l|lc|}
\hline Presenting symptoms & $\begin{array}{l}\text { Number } \\
\mathbf{N = 6 0}\end{array}$ & $\begin{array}{c}(\mathbf{\%}) \\
\mathbf{1 0 0 \%}\end{array}$ \\
\hline Chest symptoms & 33 & 55 \\
\hline CNS symptoms & 14 & 23.3 \\
\hline Abdominal symptoms & 9 & 15 \\
\hline Others & & \\
Fever & 2 & 3.3 \\
Arthralgia & 1 & 1.7 \\
Short status & 1 & 1.7 \\
\hline
\end{tabular}


Table 3:Family history of study cases:

\begin{tabular}{|l|lc|}
\hline Variables & Number & $\mathbf{( \% )}$ \\
& $\mathbf{N = 6 0}$ & $\mathbf{1 0 0 \%}$ \\
\hline Consanguinity & \multicolumn{2}{|c|}{} \\
Positive ; & 24 & 40 \\
negative & 36 & 60 \\
\hline Liver disease & 4 & 6.7 \\
\hline HCV & & \\
\hline
\end{tabular}

Regarding the anthropometric measurements of cases there were cases five with underweight four of them were wasted.(table 4).Developmental motor delay was observed in five cases $(8.3 \%$ )while global developmental delay in six cases $(10 \%$ ) and 49 were normal ( $81.7 \%$ ) (table 5)

table 4:- anthropometric measurements:

\begin{tabular}{|c|c|c|}
\hline Examination findings & Number & $(\%)$ \\
\hline $\begin{array}{l}\text { Weight /age }<5^{\text {th }} \\
5^{\text {th }}-95^{\text {th }} \\
>95^{\text {th }}\end{array}$ & $\begin{array}{l}12 \\
47 \\
1 \\
\end{array}$ & $\begin{array}{c}20 \\
78.3 \\
1.7 \\
\end{array}$ \\
\hline $\begin{array}{l}\text { Length /age } \\
<5^{\text {th }} \\
5^{\text {th }}-95^{\text {th }} \\
>95^{\text {th }}\end{array}$ & $\begin{array}{c}6 \\
53 \\
1\end{array}$ & $\begin{array}{l}10 \\
88.3 \\
1.7\end{array}$ \\
\hline $\begin{array}{l}\text { Head circumference } \\
<5^{\text {th }} \\
5^{\text {th }}-95^{\text {th }} \\
>95^{\text {th }}\end{array}$ & $\begin{array}{r}3 \\
56 \\
1\end{array}$ & $\begin{array}{l}5 \\
93.3 \\
1.7\end{array}$ \\
\hline $\begin{array}{l}\text { Weight / length } \\
<5^{\text {th }} \\
5^{\text {th }}-95^{\text {th }} 95^{\text {th }}-\end{array}$ & $\begin{array}{l}10 \\
41 \\
9\end{array}$ & $\begin{array}{l}16.7 \\
68.3 \\
15 \\
\end{array}$ \\
\hline \multicolumn{3}{|l|}{ Welcome Classification } \\
\hline Not under weight & 55 & 91.7 \\
\hline Under weight & 5 & 8.3 \\
\hline Marasmus & 0 & 0 \\
\hline Kwashiorkor & 0 & 0 \\
\hline \multicolumn{3}{|l|}{ Water-Law Classification } \\
\hline Wasted & 4 & 6.7 \\
\hline
\end{tabular}

Table 5:- Developmental history of cases:

\begin{tabular}{|l|lc|}
\hline developmental history & Number & $(\boldsymbol{\%})$ \\
\hline Normal & 49 & 81.7 \\
\hline Delayed & 11 & 18.3 \\
\hline Global & 6 & 10 \\
\hline Motor & 5 & 8.3 \\
\hline
\end{tabular}

In our study all cases had hepatomegaly, 50 cases had firm liver with sharp border and 10 cases had soft liver with rounded border.Five cases had splenomegaly(table 6)As regard liver function tests of our cases, 6 cases ( 10\% ) had elevated A.L.T. and A.S.T. but other liver fuction tests were normal.Table(7)

Table 6:- Liver and spleen examination:

\begin{tabular}{|l|cc|}
\hline & Number & \multicolumn{1}{|c|}{$\mathbf{( \% )}$} \\
$\mathbf{N = 6 0}$ & $\mathbf{1 0 0 \%}$ \\
\hline $\begin{array}{l}\text { Palpable liver below right } \\
\text { costal margin } \\
\text { Mean } \pm \text { SD }(\mathbf{c m})\end{array}$ & $5.25 \pm 1.25$ \\
\hline
\end{tabular}




\begin{tabular}{|l|lc|}
\hline Consistency & \multicolumn{2}{|c|}{} \\
Firm & 50 & 83.3 \\
Soft & 10 & 16.7 \\
\hline Span $(\mathrm{cm})$ & & \\
Mean \pm SD & $9.99 \pm 1.44$ & \\
\hline Splenomegaly & 5 cases \\
\hline
\end{tabular}

Table 7:- laboratory data of the studied cases

\begin{tabular}{|l|l|l|}
\hline Laboratory tests & Min - max & Mean \pm SD \\
\hline ALT U/L & $6-195$ & $31.08 \pm 23.68$ \\
\hline AST U/L & $7-186$ & $32.92 \pm 21.3$ \\
\hline Albumin g/dL & $3-5.6$ & $4.17 \pm 0.66$ \\
\hline Creatininemg/dL & $0.1-0.8$ & $0.25 \pm 0.15$ \\
\hline BUN mg/dL & $8-49$ & $20.1 \pm 9.63$ \\
\hline LDL $\mathrm{mg} / \mathrm{dL}$ & $65-165$ & $111.03 \pm 25.1$ \\
\hline HDL $\mathrm{mg} / \mathrm{dL}$ & $54-303$ & $123.5 \pm 42.98$ \\
\hline LDH $\mathrm{mg} / \mathrm{dL}$ & $20-609$ & $243.08 \pm 108.18$ \\
\hline
\end{tabular}

In our study we found that only four cases(6.7\%)with positive serology for $\mathrm{HCV}$.

Liver biopsy were done for these cases which revealed chronic hepatitis. (table8)

Table 8:- Cases with positive serological markers.

\begin{tabular}{|l|l|l|}
\hline Positive serology & No $=60$ & Percentage $\%$ \\
\hline HCV & 4 & 6.7 \\
\hline
\end{tabular}

\section{Discussion:-}

Viral hepatitis is a public health problem affecting approximately 5 bilion people with death of about 1 milion each year (2.7\% of all deaths) from causes related to viral hepatitis, including liver cancer (1)It can be present with hepatomegaly in only $10 \%$ of cases (Ryder and Beckingham, 2001 )(2).

Early diagnosis of these disorder (although no symptoms drive the mother to seek medical advice) give the importance of this topic.

In Egypt still some areas have poor health care system which lead to that most cases present in their late childhood by different symptoms of liver cell failure .Some of these diseases nowadays have curative treatment.

There is a limited published reports in Egypt about prevalence of viral hepatitis in children which give more value for this study.

We detected (6.7\%) of asymptomatic hepatomegaly with viral hepatitis

Alter et al (14) stated that the estimated prevalence of antibody to HCV in children up to14 years was $0.2 \%$ to $0.4 \%$ most of them asymptomatic, with chronic hepatitis C in the United States. While Zanetti et al (15) documented that even perinatally acquired hepatitis $\mathrm{c}$ infection tends to be asymptomatic in children, and the long-term outlook is not known. In our study 4 cases with HCV have family history of hepatitis. This was explained by person to person transmission and not to genetic susceptability.Zanetti et al (15) stated that the rate of mother-to-infant transmission of $(\mathrm{HCV})$ is a $5 \%$, but is higher is restricted to infants whose mothers are viraemic.

Regarding nutritional state 5 cases were under weight and 4 cases of them were wasted these cases diagnosed later as storage disease which can explain the failure to growth due to chronic liver disease.

Regarding developmental history 6 cases with global developmental delay (10 \%) 5 with delayed motor development $(8.3 \%) 2$ cases diagnosed as pompe disease, the other 3 cases under investigation. and $49(81.7 \%)$ were normal .. The five cases show pure motor developmental delay from them In our study all cases had hepatomegaly, fifty cases had firm liver( ten )cases had soft liver, and five cases had splenomegaly. As regard liver 
function tests of our cases, 6 cases ( $10 \%$ ) had elevated A.L.T. and A.S.T. and all these cases proved to had hepatitis by ELISA and PCR , no other abnormal liver functions were found.this finding suggest viral activity .

Regarding Serum albumin all cases show no abnormality which indicate no or mild hepatocellular damage which can be explained by early detection of these cases .This data agreed with Finegold(16)who reported that reduced albumin and clotting factors indicate chronic hepatocellular injury.

In our study the prevalence of HCV in asymptomatic hepatomegaly was (6.7\%) this contradict a study done by ElShafei (17) he found children with hepatomegaly in Egypt was $25.3 \%$ had HCV. We found 4 males with HCV .The incidence of HCV infection was greater in males than females.

Liver biopsy were done for four cases which revealed chronic hepatitis Finegold (16) reported that HCV representing (7\%) of cases with hepatomegaly.

Limitation; relative small number of cases and short time of the study, limited resources for investigations of inborn error of metabolism ,availability of electron microscope and immunopathology, limit this studyHowever, this study raises interesting issues requiring further investigations for better assessment of the magnitude of viral hepatitis in asympotamic children.

\section{Declaration of Funding:-}

This study was not funded.

\section{Conflict of Interest:-}

The authors declare that they have no conflict of interest.

\section{Refrences:-}

1. World Health Organization, 2009: Hepatitis C. Available at: http:// www. who. int/ vaccine research/ diseases/ viral cancers/ en/index2.html. Accessed 11/29.

2. Ryder S and Beckingham I,(2001)."Acute hepatitis". $\quad$ BMJ 322 (7279): 151153.gdoi:10.1136/bmj.322.7279.151.PMC1119417.PMID11159575 Sakka SG. Assessing liver function.CurrOpinCrit Care 2007;13:207-214.

3. El-Masry H.M., Ahmed Y.A., Hassan A.A. et al., 2007: Prevalence, Risk Factors and Impacts of Schistosomal and Intestinal Parasitic Infections Among Rural School Children in Sohag, Egypt. The Egyptian Journal of Hospital Medicine Vol., 29: 616- 630

4. Senadhi V, 2011;A paradigm shift in the outpatient approach to liver function tests. SouthMed J. 104:521-525.

5. Wyllie R andHyams JS,2006: editors: Pediatric gastrointestinal and liver disease, ed 3, Philadelphia, Saunders.

6. Lai CL, Ratziu V, Yuen M-F, et al. 2008; Viral hepatitis C. Lancet 362: 2089-94.

7. ZakariaS,Fouad R, Shaker O, et al. 2007: Changing patterns of acute viral hepatitis at a major urban referral center in Egypt. Clin Infect Dis. 15;44:e30-6

8. Deterding K, 2009;. The German Hep-Net acute hepatitis C cohort: impact of viral and host factors on the initial presentation of acute hepatitis C virus infection. Z Gastroenterol. 47:531-540.

9. Kuntzen T, et al., 2008; Naturally occurring dominant resistance mutations to hepatitis $\mathrm{C}$ virus protease and polymerase inhibitors in treatment-naïve patients. Hepatology, 48:1769-1778.

10. Medhat A,Shehata M, Magder LS, Mikhail N, Abdel-Baki L, Nafeh M, et al Hepatitis C in a community in Upper Egypt: risk 3. factors for infection. American journal of tropical medicine and hygiene, 2002, 66:633-8.

11. El-Raziky MS, El-Hawary M, Esmat G, et al.2007; Prevalence and risk factors of asymptomatichepatitis C virus infection in Egyptian children.

12. World JGastroenterol 13(12): 1828-1832

13. Bickley L, Szilagyi P, Bates B., 2009; Bate's Guide to Physical Examination and history Taking, 10th ed. Philadelphia: Wolters Kluwer Health/ Lippincott Williams \& Wilkins.

14. Alter MJ, Kruszon-Moran D, Nainan OV, McQuillan GM, Gao F, Moyer LA, et al. The prevalence of hepatitis C virus infection in the United States, 1988 through 1994. N Engl J Med. 1999;341:556-56

15. Zanetti, A.R., Tanzi, E. and Newell, M.L. (1999) Mother-to-Infant Transmission of Hepatitis C Virus. Journal of Hepatology, 31, 96-100. http://dx.doi.org/10.1016/S0168-8278(99)80383-3

16. Finegold MJ,2008; Common diagnostic problems in pediatric liver pathology.ClinLiv Dis 6:421-454.

17. El-Shafei HM (2012) Incidence of Chronic Hepatitis B and C Virus Infection in Damietta, Egypt. J Liver 1:111. doi:10.4172/2167-0889.1000111. 